\title{
A comparison between diatom assemblages in two groups of carbonate, low- altitude springs with different levels of anthropogenic disturbances
}

\author{
Nicola Angeli ${ }^{1}$, Marco Cantonati ${ }^{1}$, Daniel Spitale ${ }^{1}, \&$ Horst Lange-Bertalot ${ }^{2}$ \\ ${ }^{1}$ Museo Tridentino di Scienze Naturali, Limnology and Phycology Section, Via Calepina 14, I-38100 Trento, Italy; \\ e-mail: cantonati@mtsn.tn.it \\ ${ }^{2}$ Institute for Ecology, Evolution, Diversity, University of Frankfurt, Siesmayerstraße 70, and Senckenberg \\ Research Institute, Senckenberganlage 31-33, D-60054 Frankfurt/M., Germany
}

\begin{abstract}
Since several decades diatoms are increasingly used for the assessment of the trophic status of different freshwater ecosystems. However, spring habitats have been only marginally considered concerning this topic. The purpose of this research was to compare the diatom assemblages of two groups of carbonate, low-altitude springs, affected by different levels of anthropogenic disturbances. Between 2005 and 2008, diatoms were sampled in 57 low-altitude, carbonate springs, keeping separate the main microhabitats (stones and bryophytes), and assessing an extensive number of morphological, physical, and chemical variables. Two datasets were considered for the present paper: the first (CESSPA, $\mathrm{N}=25$ ) includes carbonate springs located within the River Adige catchment, the second (CRENODAT selected springs, $\mathrm{N}=32$ ) includes springs located not exclusively within the same basin, and very similar to the previous ones as regards lithological substratum, altitude range, shading. Trophic and saprobity indices, together with multivariate techniques, were used to assess differences between the diatom assemblages in the two datasets. Indices revealed higher trophic and saprobic levels for the CESSPA springs than for the other group (CRENODAT). Values of the Shannon-Wiener diversity index were similar for the two groups while the average richness was slightly higher in nature-near springs (CRENODAT); higher percentages of endangered or rare taxa (Red List) were found only in the nature-near springs. The main impacts affecting the CESSPA springs were found to be both anthropogenic disturbances, such us water abstraction and spring-bed modification, and higher nitrate values. The importance of the fine tuning of diatom-based bioassessment methods in spring habitats is stressed.
\end{abstract}

Key words: springs, diatoms, nitrates, morphology, carbonate substratum, eutrophication, low altitude, anthropogenic impacts

\section{Introduction}

Springs, besides being obviously important as resources for good-quality water, are also relevant habitats with peculiar characteristics (CANTONATI et al. 2006).

During the 1990s, some comprehensive studies on the diatom assemblages of springs were performed considering nature-near, rheocrene sources at mid- and high elevations in large mountain ranges (Pyrenees: SABATER \& Roca 1990, 1992; Alps: CANTONATI 1998a). Lowaltitude, carbonate springs in densely populated areas, directly affected by different kinds of impacts were less considered. However, some information on this type of springs is meanwhile available for springs located in Spain (ABOAL et al. 1998; Delgado et al. 2007, Mallorca), France (BERTRAND et al. 1999), Switzerland (ТАХвÖCK \& Preisig 2007), Poland and Turkey (Wojtal 2006; WoJTAL \& SolaK 2009). An investigation on the diatoms of the crenon and epirhithron zones of Apennine streams (central Italy) was recently published by ToRrisi \& DeLL'UOMO (2009).

According to Cantonati (1998a) and Cantonati et al. (2006) the most relevant environmental variables in shaping spring diatom assemblages are $\mathrm{pH}$ and conductivity, inorganic nitrogen, substratum-particle size, and shading. The frequently leading role of $\mathrm{pH}$ and conductivity in shaping diatom assemblages was noted in several investigations on different aquatic habitats including springs (e.g. PoulíčKová et al. 2004). These geogenic variables, however, were 
not supposed to be of prominent relevance in this investigation that considered springs on carbonate substratum only. CANTONati et al. (2006) argue that altitude is an important variable for diatom assemblages in springs only if large altitude differences are considered. In a literature review on environmental controls of freshwater diatoms, SoININEN (2007) identified ion concentration and trophic status as major drivers of diatom distribution in lakes and streams at a regional scale.

With the aim of improving our understanding of the response of spring diatom assemblages to anthropogenic disturbances, we selected two datasets characterized by high and low impacts respectively. The main objectives of this study were the following: (1) to evaluate floristic and environmental quality differences using the diatom Red List; (2) to evaluate the differences by applying widely used running-water, diatombased indices (trophism, saprobity, and moisture); (3) to evaluate whether the diatom assemblages differed significantly between the two groups of springs, and (4) to point out the eventual most relevant impacts.

\section{Materials and methods}

\section{Datasets \& study area}

For this study two datasets were used. The first one, named CESSPA (because it comprises springs sampled during the Project CESSPA, Censimento e studio di sorgenti e pozzi del Bacino dell'Adige = Inventory and investigation of springs and wells in the River Adige basin, 2007-2009), includes 25 springs located within the River Adige Basin and ranging across an altitudinal gradient from 62 to $1266 \mathrm{~m}$ a.s.l. (Fig. 1). The second, named CRENODAT, was a selection of 32 springs investigated during the homonymous Project (CRENODAT, "Biodiversity assessment and integrity evaluation of springs of Trentino - Italian Alps - and long-term ecological research", 20042007) that considered more than one hundred springs in the Autonomous Province of Trento (CAnTONATI et al. 2010). From this larger dataset, only the springs (N $=32)$ at similar altitude $(<1052 \mathrm{~m}$ a.s.l.), and lithology (limestones) to the CESSPA ones were selected and used for the present work. Thus the two groups of springs were comparable as regards the region, the altitudinal range, and the geogenic factors. The first group (CESSPA) was however supposed to be more disturbed than the second (CRENODAT; Fig. 2).

The springs are located in the south-eastern Alps in the Veneto Region (CESSPA) and in the Autonomous Province of Trento (CRENODAT). More

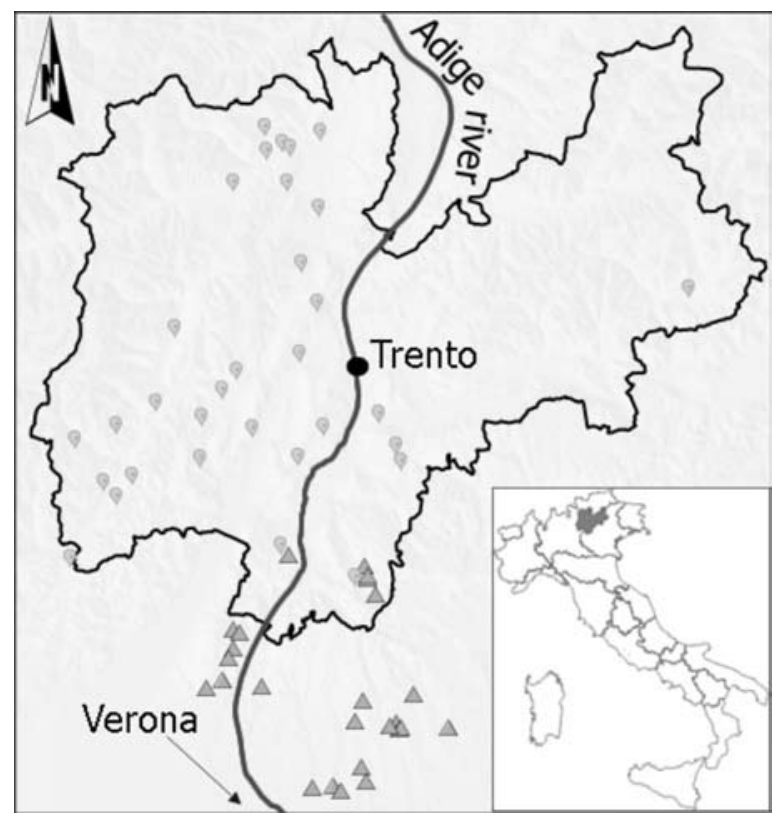

Fig. 1. Location of the springs studied. Triangles $=$ CESSPA springs, drops $=$ CRENODAT springs. The solid line delimits the borders of the Autonomous Province of Trento, Italy.

specifically, for the CESSPA project, only springs within the River Adige basin were considered, whereas the CRENODAT springs were not exclusive of that basin. The main difference supposed to be relevant for this study were the different levels of anthropogenic disturbance affecting the CRENODAT and the CESSPA springs. As regards the former, $3 / 4$ of the springs can be considered natural while for the latter only $1 / 4$ had no assessed disturbances.

\section{Sampling surveys}

Geographical position and altitude of the springs were recorded by a GPS (GPSMAP 76S Garmin). Temperature was measured with a digital probe, and maximum current velocity with a propeller current meter (OTT Messtechnik, Kempten, Germany), which was used also to assess discharge in large springs with the velocity / area method. However, for the majority of the springs under consideration, discharge was measured using a graduated bucket repeating the measurement in different parts of the spring.

Current velocity and shading conditions were assessed using five-point scales described in detail in Cantonati et al. (2007) and in Cantonati \& Spitale (2009). As regards other ecomorphological variables and parameters, the methods discussed in Spitale (2007) were used.

Anthropogenic disturbances were evaluated in an ordinal scale, considering water-collection systems, roads, buildings, alterations to the spring bed, forestry, farming and cattle-breeding activities. We gave a score to disturbance $(1=$ low; $2=$ medium; $3=$ high), which referred to the distance between the 
presumed impact and the spring area. For example, we assigned a high impact if a partial water-collection system existed very close to the water source, and a lower impact if the water-collection was more distant, downstream. If different types of disturbances occurred within the same spring (for example, water collection plus roads), we summed the scores. By summing the impacts affecting the spring, we obtained the total disturbance. Although the maximum potential score for anthropogenic disturbance could be $21(=7 \times 3)$, the resultant was expressed as a continuous variable from 0 to 10 , the latter being the highest impact recorded in this study.

\section{Hydrochemical analyses}

Water for hydrochemical analyses was collected in acid cleaned graduated bottles, which were rinsed several times with spring water before sampling. As regards the CRENODAT Project, analyses $(\mathrm{pH}$ at $20{ }^{\circ} \mathrm{C}$, conductivity, alkalinity, total hardness, $\mathrm{Ca}^{2+}$, $\mathrm{Mg}^{2+}, \mathrm{Na}^{+}, \mathrm{K}^{+}, \mathrm{Cl}^{-}, \mathrm{NH}_{4}^{+}, \mathrm{NO}_{3}^{-}, \mathrm{NO}_{2}^{-}, \mathrm{SO}_{4}^{2-}$ ) were carried out in the labs of the Agriculture Institute of S. Michele all'Adige (Trento) following standard methods (APHA 2000). As regards the CESSPA Project, the same parameters were analysed following national standard methods substantially very similar to APHA (2000). Two Institutes carried out the analyses: the Environmental Agency of the Veneto Region for 12 springs (Buso delle Anguane, Biuchele Speccheri, Boschi, Brusaferri, Val di Canova, Cocher, Fondo Comperlon, Ferrara, Lodrone, Monte Catini, Pezza and Veraghi), and the Istituto Fermi for the remaining CESSPA springs (Table 1).

\section{Diatoms, and data analysis}

The substrata considered for the investigation of diatom assemblages were sampled separately. Epilithic diatoms were collected by brushing seven to ten cobbles or small boulders (KeLLy et al. 1998). For the epibryon, the dominant bryophyte species (submerged or the close to the water) was collected. These bryophytes sampled as supports for the investigation of the epilithic diatoms were carefully identified; in order of frequency, they were: Cratoneuron filicinum (Hedw.) Spruce (9), Palustriella commutata (Hedw.) Ochyra (4) Brachythecium rivulare Schimp. (4), Platyhypnidium riparioides (Hedw.) Dixon (5), Eurhynchium pulchellum (Hedw.) Jenn. (2), and Cinclidotus aquaticus (Hedw.) Bruch \& Schimp. (1).

The field samples were treated with hydrogen peroxide and hydrochloric acid (KRAMMER \& LANGE-BERTALOT 1986, EN 13946), and cleaned valves were mounted in Naphrax ${ }^{\circledR}$ (Brunel Microscopes Ltd., Chippenham, Wiltshire, UK). Slides, prepared material, and aliquots of the original samples both for CESSPA and CRENODAT springs were deposited in the diatom collection of the Museo Tridentino di Scienze Naturali (accession numbers of the samples collected in the
CESSPA springs: cLIM007 DIAT 637-683; for the CRENODAT springs accession numbers see Cantonati et al. 2010b, in prep.).

Three permanent mounts were prepared for each sample, and a total of 400-500 valves were counted to assess relative abundances. All slides where then scanned for taxa with low relative abundances for several hours. Identification and nomenclature followed mainly Krammer \& LANGE-BERTALOT (19861991), Lange-Bertalot \& Krammer (1989), Round et al. (1990), Lange-Bertalot (1993, 2001), LangeBertalot \& Metzeltin (1996), Krammer (1997a,b, 2000-2003), Krammer \& LANGe-Bertalot (2004), Reichardt (1997, 2000-2003), and Werum \& LANGEBerTALOT (2004).

Light microscope observations and micrographs were conducted using a Zeiss Axioskop 2 microscope (Zeiss, Jena, Germany) equipped with phase-contrast and with an Axiocam digital camera. SEM observations were made at the Museo Tridentino di Scienze Naturali using a LEO XVP (Carl Zeiss SMT Ltd., Cambridge, $\mathrm{UK})$ at high vacuum on gold coated prepared material.

\section{Data processing and statistical analyses}

For a first characterization of selected ecological requirements, moisture ( $=$ need for water of the individualdiatom species), trophic status, and saprobity as reported in VAN DAM et al. (1994) were considered. A more objective indication of rarity was gained from the Red List published by LANGe-Bertalot (1996). A version of this check-list with symbols' explanations in English is available in RuMrICH et al. (2000). The trophic status of the springs was evaluated by using the diatom-based Trophieindex $\left(\mathrm{TI}_{\mathrm{DIA}}\right)$ by RoTT et al. (1999). Shannon-Wiener Diversity Index (SHAnNON 1948) was calculated using 2-based logarithms.

To compare the number of species recorded in sets of samples with different sampling effort (different numbers of springs) we used the species accumulation curves (MagurRan 2004). Species accumulation curves show the rate at which new species are found within a community, and allow an estimate of species to be extrapolated. The cumulative number of species recorded is plotted as a function of sampling effort (i.e. number springs). Since the order in which the samples are included influences the curve shape, the process was repeated 99 times, and then the mean of these permutations was plotted.

Multivariate data analyses were used to describe and examine the differences between diatom spring assemblages of different areas (CESSPA vs CRENODAT). Springs were ordered by using the method of non-metric, multidimensional scale (n-MDS) to summarize the main gradients. Ordination was computed on the Bray-Curtis similarity matrix of species data (LEGENDRE \& LEGENDRE 1998). Before running the n-MDS, data were square-root transformed to restrict the influence of abundant taxa on the results 
of the ordination (Legendre \& Legendre 1998). To test for differences between the two groups we used One-way Analysis of Similarity (ANOSIM) (CLARKE \& WARWICK 1994).

\section{Results}

\section{Abiotic differences between CESSPA and CRENODAT springs}

Since both spring groups were located on carbonate substrata, $\mathrm{pH}$ and conductivity showed relatively restricted ranges (Fig. 2). The mean values of $\mathrm{pH}$ were slightly different (7.9 vs 7.6) for CRENODAT and CESSPA respectively. On the contrary, the mean conductivity was higher for CESSPA than for CRENODAT (453 vs 337 $\left.\mu \mathrm{S} . \mathrm{cm}^{-1}\right)$ springs. Nitrate concentrations were clearly higher (almost double) in the CESSPA springs, whereas discharge was several times higher for the CRENODAT springs (mean: 3.3, $\max 35$, min. $0.11 . \mathrm{s}^{-1}$ ) than for CESSPA springs (mean: 0.4, $\max 2$, min $0.0041 . \mathrm{s}^{-1}$ ). Anthropogenic disturbances were clearly higher for CESSPA springs than for the CRENODAT ones (Fig. 2). Water temperatures and shading were quite similar in the two spring groups (Fig. 2),

Main ions $\left(\mathrm{SO}_{4}^{2-}, \mathrm{Cl}^{-}, \mathrm{Ca}^{2+}, \mathrm{Na}^{+}\right.$, and $\mathrm{K}^{+}$), except for $\mathrm{Mg}^{2+}$, were slightly higher for CESSPA springs. More detailed accounts of the hydrochemical characteristics of the CESSPA and CRENODAT springs are planned to be published in forthcoming publications.

Diatoms assemblages' composition, taxa richness and diversity

A total of 138 diatom taxa, belonging to 40 genera, were found in the CESSPA samples (epibryon and epilithon). The genera with the highest numbers of taxa were: Nitzschia (17), Navicula (14), Gomphonema (12), followed by Diploneis (6), Fallacia, Encyonema, Diadesmis and Caloneis (5), Psammothidium, Fragilaria, Encyonopsis, Cymbella, Amphora and Achnanthidium (4), and by Surirella, Sellaphora, Planothidium, Diatoma and Adlafia (3). The most frequent and abundant taxa together with locally abundant taxa, and frequently occurring taxa but with low abundance are shown in Table 2. A complete list including all taxa observed will be published in a forthcoming paper on the diatom biodiversity of these low-altitude, carbonate springs affected by nitrate pollution and by alteration of their
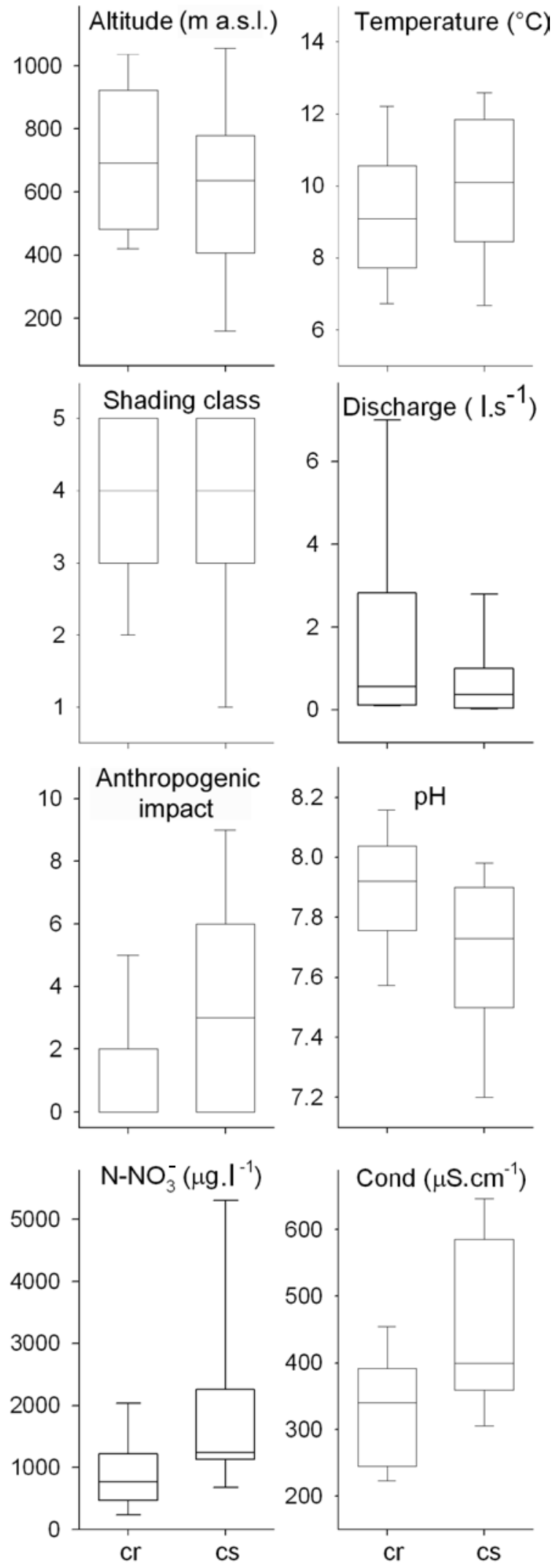

Fig 2. Box plots of the most relevant abiotic variables characterizing CESSPA (cs) and CRENODAT (cr) springs. 


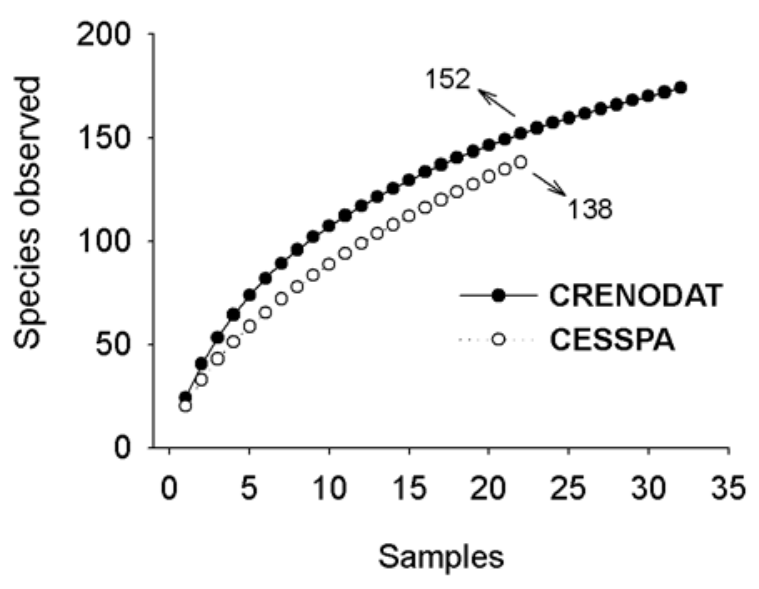

Fig 3. Species accumulation curves of the diatoms sampled in the CESSPA and CRENODAT springs. Average species richness is based on 999 randomized permutations.

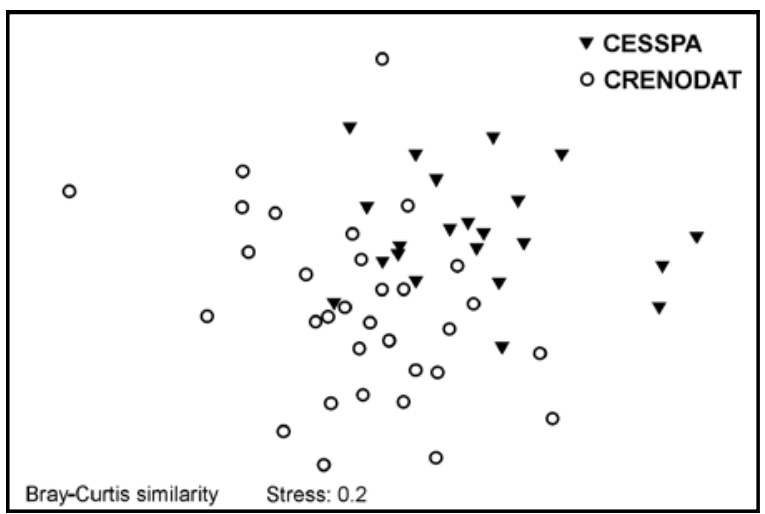

Fig 4. Non-metrical multidimensional scaling of the two groups of springs based on a Bray-Curtis similarity matrix after square root transformation of the diatom relative abundance data. (Stress is a measure of the agreement between distances and dissimilarities. The lower the stress the better the representation on the diagram. Rules of thumb suggest that nMDS ordinations with stress values up to about 0.2 can be ecologically interpretable and useful, whereas values greater than 0.3 indicate that the points are close to being arbitrarily placed.

ecomorphology.

A total of 175 diatom taxa, belonging to 35 genera, were found in the CRENODAT samples (epibryon and epilithon). The genera with the highest number of taxa were Gomphonema (21), Navicula (16), and Cymbella (14), followed by Achnanthidium (10), Nitzschia (12), Fragilaria (10), Diploneis (9), Encyonopsis, Caloneis (6), Encyonema, Cocconeis, Pinnularia, Amphora (5), Brachysira, Eunotia, Psammothidium, Sellaphora (4) and by Diatoma, Denticula, Planothidium (3). The most frequent and abundant taxa together with locally abundant taxa and frequently occurring but with low abundance are shown in Table 3 .

The detailed taxonomic study of the material sampled in the CESSPA springs allowed to observe several rare and poorly known diatom species (e.g. Caloneis sp., Fallacia cf. losevae LANGE-Bertalot et al. Even a new diatom species belonging to the genus Navicula sensu stricto (Lange-Bertalot 2001) and similar to N. cincta (EHRENBERG) RaLfS was found in the Torricelle spring (epibryon sample): Navicula veronensis (unpublished).

On the average, for CESSPA sites, 16 (epibryon) and 13 (epilithon) taxa, and a mean Shannon-Wiener Diversity Index of 2.4 (epibryon) and 1.9 (epilithon) were found. The maximum number of taxa (31) was found in an epibryon sample taken in Buso delle Anguane, a site with only partially-modified morphology and average hydrochemical characteristics, and the minimum (7 taxa) in the epibryon sample of Val di Canova, a captured spring. No diatoms were found in Veraghi (partially-modified morphology) epibryon sample and Squarà (artificial pond) epibryon and epilithon samples. In the Boschi and Pezza captured springs none of the substrata considered for diatom analysis in this investigation was available. Similar results were found with the Diversity Indices: Maximum values (3.9) in Buso delle Anguane epibryon sample and minimum value (0.6) for Val di Canova and Fonte Grande epilithon samples. A low value of the Diversity Index (1.0) was found also for the bryophyte sample taken in Malga Lonza, another spring with partially-modified morphology.

On the average, for the CRENODAT sites, 19 (epibryon) and 12 (epilithon) taxa and a mean Shannon-Wiener Diversity Index of 2.4 (epibryon) and 1.9 (epilithon) were found. The maximum taxa number (39) was found in an epibryon sample taken in Laurel, a close-tonatural spring on carbonate substratum and the minimum (3 taxa) in the stone sample of Frana Edene. For Fiavè, Sass Ross, and Vallarsa only epibryon samples could be used for the diatom investigation, since no diatoms were found in the epilithon samples. Similar results were found with the Diversity Indices: maximum values (3.6) in Laurel epibryon sample, and minimum value (1.0) in Laurel and Terres epilithon samples.

Accumulation curves calculated for the species recorded in CESSPA and CRENODAT springs showed that the difference between the two groups was evident, with a general 
Table 1. Spring names, codes, sampling dates, altitude and GPS coordinates for the CESSPA springs.

\begin{tabular}{lccccc}
\hline Spring's name & Spring's code & Date & Altitude m (a.s.l.) & Latitude & Longitude \\
\hline Balladoro & ML0125 & 6.2 .2008 & 125 & 5037380 & 1660193 \\
Biasetti & ML0533 & 23.10 .2008 & 533 & 5046804 & 1669130 \\
Biuchele Speccheri & MP0676 & 5.7 .2007 & 676 & 5070192 & 1665583 \\
Boschi & ML0690a & 24.9 .2007 & 690 & 5047318 & 1670049 \\
Brusaferri & ML0675 & 13.3 .2008 & 675 & 5051937 & 1672892 \\
Buso delle Anguane & ML0370 & 7.9 .2007 & 370 & 5046755 & 1678428 \\
Cocher & MP0690b & 5.7 .2007 & 690 & 5072022 & 1665120 \\
Fenil dei Coltri & MB0894 & 5.3 .2008 & 894 & 5057536 & 1643517 \\
Fondo Comperlon & MP0924 & 28.6 .2007 & 924 & 5067618 & 1666806 \\
Fontana della Teja & MB1215 & 13.3 .2008 & 1215 & 5061690 & 1645390 \\
Fonte del Coppo & ML0183 & 24.10 .2008 & 183 & 5038190 & 1665273 \\
Fonte Grande & ML0637 & 23.1 .2008 & 637 & 5046661 & 1670882 \\
Gaon & ML0385 & 5.3 .2008 & 385 & 5052828 & 1640084 \\
La Ferrara & ML0640 & 24.9 .2007 & 640 & 5046371 & 1670635 \\
Lodrone & MB0517 & 11.7 .2007 & 517 & 5073869 & 1653006 \\
Malga Lonza & MB1266 & 13.3 .2008 & 1266 & 5062144 & 1644238 \\
Monte Catini & MB0840 & 2.8 .2007 & 840 & 5059040 & 1644303 \\
Pezza & ML0428 & 4.10 .2007 & 428 & 5040318 & 1664523 \\
Prealba & MB0445 & 5.3 .2008 & 445 & 5054177 & 1642679 \\
Squarà & ML0062 & 6.2 .2008 & 62 & 5036691 & 1661389 \\
Torricelle & ML0220 & 6.2 .2008 & 220 & 5037056 & 1656719 \\
Vajo del Croce & ML0580 & 24.1 .2008 & 580 & 5047665 & 1663592 \\
Val di Canova & MP0720 & 13.6 .2007 & 720 & 5070502 & 1665547 \\
Varalta & ML0950 & 24.1 .2008 & 950 & 5051000 & 1664703 \\
Veraghi & ML0622 & 28.8 .2007 & 622 & 5053017 & 1648879 \\
\hline & & & & &
\end{tabular}

occurrence of more species-rich sites within the CRENODAT springs (Fig. 3). When comparing the two groups considering the same sampling effort, the difference was not high but appreciable (138 species in CESSPA and 152 in CRENODAT). In addition, spring ordination by nMDS (Fig. 4) and subsequent ANOSIM test revealed that the two diatom assemblages, CESSPA and CRENODAT, were significantly different after 9999 permutations $(\mathrm{R}=0.239, \mathrm{P}<0.001)$.

Red List status was available for about $70 \%$ of the taxa found in the 25 CESSPA springs. An interesting result was the low percentage (24\%) of endangered or probably menaced and rare taxa according to Red List, while more than $60 \%$ of the taxa could be classified as surely not endangered (Fig. 5). Red List status was available for about $69 \%$ of the taxa found in the 32 CRENODAT springs. The percentage of the taxa belonging to endangered or probably menaced and rare taxa according to Red List high was relatively high (47\%) (Fig. 5).

\section{Diatom assemblages and related physico- chemical variables}

Concerning the moisture preferences, as reported in VAN DAM et al. (1994), these were available for about $44 \%$ of the CESSPA taxa found. $51 \%$ of diatom taxa were found mainly in water bodies, also rather regularly on wet and moist places, while $18 \%$ was typical of wet and moist or temporarily dry places (Fig. 6). Environmental preferences for CRENODAT diatom assemblages were available for $47 \%$ of the whole assemblage. As many as $45 \%$ of these were found mainly in water bodies, also rather regularly on wet and moist places, while $20 \%$ was typical of wet and moist or temporarily dry places (Fig. 6).

Almost $22 \%$ of the 64 CESSPA taxa found for which this information was available (VAN 
Table 2. Most frequent and / or abundant taxa found in the CESSPA springs.

\begin{tabular}{|c|c|c|}
\hline & $\begin{array}{c}\text { MAX } \\
(\%)\end{array}$ & $\begin{array}{c}\mathrm{N}^{\circ} \text { of samples } \\
\text { (epibryon+epili- } \\
\text { thon) }\end{array}$ \\
\hline \multicolumn{3}{|l|}{$\begin{array}{l}\text { The most frequent and abundant taxa ( }>5 \text { samples; relative abundances } \\
\geq 15 \%)\end{array}$} \\
\hline Achanthidium minutissimum (KÜTZING) CZARNECKI & 92,6 & 41 \\
\hline Achanthidium pyrenaicum (HustedT) KoBAYAsI & 71,9 & 51 \\
\hline Diadesmis contenta (Grunow ex V. Heurck) MAnN & 57,3 & 16 \\
\hline Amphora inariensis KRAMMER & 40,2 & 33 \\
\hline Diatoma mesodon (EHRENBERG) KÜTZING & 38,6 & 16 \\
\hline Eolimna minima (GRUNOW) LANGE-BERTALOT & 36,2 & 51 \\
\hline Denticula tenuis KüTZING & 34,2 & 9 \\
\hline Sellaphora joubaudii (H. Germain) M. AbOAL & 33,7 & 17 \\
\hline Amphora normannii RABENHORST & 27,3 & 8 \\
\hline $\begin{array}{l}\text { Caloneis fontinalis (GRUnOw) LANGE-BerTalot et ReICHARDT in LANGE-Ber- } \\
\text { TALOT \& METZELTIN }\end{array}$ & 24,6 & 31 \\
\hline Amphora pediculus (KÜTZING) GRUNOW & 22,8 & 37 \\
\hline Cocconeis placentula var. euglypta (EHRENBERG) GRUNOW & 20,2 & 20 \\
\hline Planothidium lanceolatum (BRÉB.) LANGE-BERTALOT & 20,2 & 27 \\
\hline \multicolumn{3}{|l|}{ Taxa abundant only in one or few sites were ( $£ 3$ samples; $>15 \%$ ) } \\
\hline Nitzschia fonticola GRUNOw in Cleve et MölleR & 44,1 & 2 \\
\hline Nitzschia lacuum LANGE-BERTALOT & 22,0 & 2 \\
\hline Eolimna tantula (HustedT) LANGE-BERTALOT in WERUM et LANGE-BERTALOT & 20,8 & 3 \\
\hline Nitzschia perminuta (Grunow) M. Peragallo & 18,3 & 1 \\
\hline \multicolumn{3}{|l|}{ Frequently occurring ( $>10$ samples abundances; $<3 \%)$} \\
\hline Navicula cryptotenella LANGE-BERTALOT & 2,3 & 11 \\
\hline Nitzschia linearis W.M. Sмітн & 1,9 & 12 \\
\hline Adlafia minuscola var. muralis (GRUNOW) LANGE-BERTALOT & 1,0 & 51 \\
\hline
\end{tabular}

DAM et al. 1994), is typically oligotraphenticoligomesotraphentic, 61\% mesotraphentic-eutraphentic and 17\% oligo-eutraphentic (Fig. 7). Almost $36 \%$ of the 87 CRENODAT taxa found for which this information was available $(50 \%$ of the total composition), is typically oligotraphenticoligomesotraphentic, 48\% mesotraphentic-eutraphentic, and 16\% oligo-eutraphentic (Fig. 7).

The $40.3 \%$ of the 67 CESSPA taxa for which the information was available (49\% of the overall biodiversity; VAN DAM et al. 1994) were oligosaprobic, and $41.8 \%$ were tolerant to $\beta$-mesosaprobic, $10.4 \%$ to $\alpha$-mesosaprobic, and $7.5 \%$ to $\alpha-$ mesosaprobic/polysaprobic conditions (Fig. 8). 56.4\% of the 94 CRENODAT taxa for which the information was available (54\% of the overall biodiversity) was oligosaprobic, and 27.7 tolerant to $\beta$-mesosaprobic, 8.5 to $\alpha$-mesosaprobic, and 7.4 to $\alpha$-mesosaprobic/ polysaprobic conditions (Fig. 8).

For what concerns $\mathrm{pH}$ preferences (VAN DAM et al. 1994), as expected, the majority of both the CESSPA $(69.1 \%$ of the 68 taxa for which this information was available $=49 \%$ ) the CRENODAT taxa (53.2\% of the 94 taxa for which this information was available $=54 \%$ ) were alkaliphilous (Fig. 9).

Rott's Trophic Index (RoTT et al. 1999) based on epibryon and epilithon diatom samples (CESSPA) was available for the taxa making up on average about $70 \%$ of the diatom assemblages. Recorded values were very similar for both 
Table 3. Most frequent and / or abundant taxa found in the CRENODAT springs.

\begin{tabular}{|c|c|c|}
\hline & $\begin{array}{c}\text { MAX } \\
(\%)\end{array}$ & $\begin{array}{c}\mathrm{N}^{\circ} \text { of samples } \\
\text { (epibryon+epilithon) }\end{array}$ \\
\hline \multicolumn{3}{|l|}{$\begin{array}{l}\text { The most frequent and abundant taxa ( }>5 \text { samples; relative abundances } \\
\geq 15 \% \text { ) }\end{array}$} \\
\hline Achnanthidium minutissimum (KÜTZING) CZARNECKI & 89,1 & 59 \\
\hline Achnanthidium pyrenaicum (HustedT) KOBAYASI & 87,0 & 41 \\
\hline Cocconeis placentula var. lineata (EHRENBERG) VAN HEURCK & 72,6 & 16 \\
\hline Tetracyclus rupestris BRAUN in RABENHORST & 65,1 & 10 \\
\hline Amphora pediculus (KÜTZING) GRUNOW & 57,3 & 44 \\
\hline Achnanthidium strictum E. REICHARDT & 55,4 & 12 \\
\hline Achanthidium dolomiticum CANTONATI et LANGE-BERTALOT & 45,9 & 9 \\
\hline Nitzschia dissipata (KÜTZING) GRUNOW & 39,5 & 7 \\
\hline Gomphonema pumilum var. elegans E. REICHARDT et LANGE-BERTALOT & 34,7 & 12 \\
\hline Diatoma mesodon (EHRENBERG) KÜTZING & 33,1 & 33 \\
\hline \multicolumn{3}{|l|}{ Caloneis fontinalis (Grunow) LANGE-BERT. et ReICHARDT in LANGE-BERTALOT } \\
\hline Planothidium lanceolatum (BRÉBISSON) Round et BUKHTIYAROVA & 30,4 & 32 \\
\hline Eunotia arcubus NÖRPEL-SCHEMPP et LANGE-BERTAlOt in LANGE-BERTALOT & 25,7 & 10 \\
\hline Encyonopsis microcephala (GRUNOw) KRAMMER & 25,4 & 15 \\
\hline Cocconeis placentula var. euglypta (EHRENBERG) GRUNOW & 21,6 & 28 \\
\hline Delicata delicatula (KÜTZING) KRAMMER & 19,8 & 9 \\
\hline Sellaphora joubaudii (H. GERMAIN) M. ABOAL & 19,1 & 7 \\
\hline Encyonopsis falaisensis (GRUNOW) KRAMMER & 18,4 & 7 \\
\hline Gomphonema lateripunctatum REICHARDT et LANGE-BERTALOT & 17,3 & 10 \\
\hline Navicula cryptotenella LANGE-BERTALOT & 15,7 & 11 \\
\hline \multicolumn{3}{|l|}{ Taxa abundant only in one or few sites were ( $£ 3$ samples; $>15 \%$ ) } \\
\hline Delicata minuta KRAMMER & 28,9 & 3 \\
\hline Caloneis aerophila Bock & 27,6 & 1 \\
\hline Gomphonema minutum (AgARDH) AgARDH & 16,7 & 3 \\
\hline \multicolumn{3}{|l|}{ Frequently occurring ( $>10$ samples abundances; $<3 \%$ ) } \\
\hline Adlafia minuscula (GRUNOw) H. LANGE-BERTALOT & 2,5 & 11 \\
\hline Planothidium dubium (Grunow) Round et BuKHT & 1,8 & 11 \\
\hline
\end{tabular}

substrata $($ mean $=1.9 / 1.9 ; \max =3.1 / 3.2 ; \min$ $=1.0 / 1.1$ epibryon / epilithon respectively). Considering Rott's Trophic Index based on epilithon samples, there are no ultraoligotrophic springs, $30 \%$ are oligotrophic, $15 \%$ oligomesotrophic, 5\% mesotrophic, 25\% mesoeutrophic, $5 \%$ eutrophic, and $15 \%$ eu-polytrophic (Fig. 10). Rott's Trophic Index based on epibryon and epilithon diatom samples (CRENODAT) was available for the taxa making up on average about
$78 \%$ of the diatom assemblages. Recorded values were very similar for both substrata (mean $=1.6$ / 1.6; $\max =2.8 / 2.5 ; \min =0.6 / 0.7$ epibryon / epilithon respectively) (Fig. 10). Considering Rott's Trophic Index based on epilithon samples $10.3 \%$ of the springs are ultraoligotrophic, $31 \%$ oligotrophic, $10.3 \%$ oligo-mesotrophic, $24.1 \%$ mesotrophic, $10.3 \%$ meso-eutrophic, $13.8 \%$ eutrophic (Fig. 10).

Figure 11 shows a cluster analysis 



Fig 5. (5) Red List status (based on diatom taxa found both in the epilithon and in the epibryon) according to Lange-Bertalot (1996): (A) extinct or disappeared, (B) threatened with extinction, (C) severely endangered, (D) endangered, (E) presumed endangered, (F) extremely rare, $(\mathrm{G})$ decreasing, $(\mathrm{H})$ at present not threatened, (I) surely not threatened, (J) data scarce, $(\mathrm{K})$ likely to occur in central Europe.

Fig. 6. Moisture preferences (based on diatom taxa found both in the epilithon and in the epibryon) according to VAN DAM et al. (1994): (1) never, or only rarely, occurring outside water bodies, (2) mainly occurring in water bodies, sometimes on wet places, (3) mainly occurring in water bodies, also rather regularly on wet and moist places, (4) mainly occurring on wet and moist or temporarily dry places, (5) nearly exclusively occurring outside water bodies.

Fig. 7. Trophic preferences (based on diatom taxa found both in the epilithon and in the epibryon) according VAN DAM et al. (1994): (1) oligotraphentic, (2) oligo-mesotraphentic, (3) mesotraphentic, (4) meso-eutraphentic, (5) eutraphentic, (6) hypereutraphentic, (7) oligo- to eutraphentic. 
performed on the CESSPA springs (spring codes are available in Table 1). The groups found are clearly placed along a gradient of increasing nitrate concentrations and anthropogenic disturbance (see the Methods section for a detailed explanation of the disturbance gradient: Alteration of the spring mouth's morphology due to spring capturing).

\section{Discussion}

The present investigation allowed the ecological characterization of the diatom assemblages of a spring type rather understudied so far: low-altitude (pre-Alpine mountains and hills), carbonate springs in densely populated areas. The comparison with a selection of springs with similar ecomorphological and geochemical characteristics, located in a nearby geographic area less affected by anthropogenic impacts, allowed to point out that the diatom assemblages of the springs investigated are disturbed both by an increased trophic status (nitrates) and by widespread alterations of the morphology of the spring area due to spring capturing. This was evident comparing the two groups of springs on the basis of diatom trophic indices (RotT et al. 1999), numbers of taxa, and Shannon diversity, but also proportions of endangered Red List taxa.

The diatom communities found show similarities with the few papers dealing with more or less impacted, low-altitude, carbonate springs, e.g. the relevant number of taxa of the genus Nitzschia observed also by WoJTAL \& SolaK (2009) in springs affected by high anthropogenic pressure in Turkey, or the important occurrence of Amphora normannii Rabenhorst found also by ToRrisi \& Dell'Uomo (2009) in only moderatelyimpacted low-altitude springs and first-order watercourses of the Apennines.
The CRENODAT springs used in the comparison appear to have been selected with criteria optimizing the comparison possibilities. Indeed, the two groups of springs are very similar as concerns altitude, temperature, $\mathrm{pH}$, and shading (Fig. 2). Even the picture of moisture-preference groups found for the diatom assemblages of the two groups of springs (Fig. 6) is almost identical, suggesting very similar flow regimes. Also the lithological substratum (different types of carbonate rocks) is similar for the two groups of springs (CRENODAT/CESSPA). A partial exception to this statement may be the fact that some CRENODAT sites are influenced in a relevant way by dolomite rock in the drainage basin. This may indeed be the explanation for the higher magnesium values found in the CRENODAT springs.

The diatom assemblages of the CESSPA springs appear to be characterized by a relatively low proportion of endangered Red List taxa (24\%). This fact can be surely related both to the greater proportion $75 \%$ of disturbed or captured springs investigated in the frame of the CESSPA project against $25 \%$ of the CRENODAT ones, and to the much higher nitrate concentrations found in the CESSPA springs. It may be remembered for comparison that other well preserved special aquatic habitats of the Alps (springs, high mountain lakes) were found to host about $50 \%$ of threatened Red List species (CANTONATI 1998; TоLотті 2001) and that this number reduced to about $30 \%$ considering springs in more densely inhabited areas (mountains of central Germany, Werum \& Lange-Bertalot 2004; Swiss preAlpine springs of the areas of Basel and Zürich, TАХвÖCK \& PREISIG 2007). This number further reduced to about $8 \%$ in nitrate-polluted springs of Bavaria (FrITSCHER 2004).

Also the total number of diatom taxa

Fig. 8. Saprobity preferences (based on diatom taxa found both in the epilithon and in the epibryon) according to VAN DAM et al. (1994): (1) oligosaprobic, (2) b-mesosaprobic, (3) a- mesosaprobic, (4) a-meso-/polysaprobic, (5) polysaprobic.

Fig. 9. $\mathrm{pH}$ preferences (based on diatom taxa found both in the epilithon and in the epibryon) according to VAN DAM et al. (1994): (1) acidobiontic ( $\mathrm{pH}<5.5)$, (2) acidophilous ( $\mathrm{pH}<7)$, (3) circumneutral ( $\mathrm{pH}$ about $=7$ ), (4) alkaliphilous $(\mathrm{pH}>7),(5)$ alkalibiontic ( $\mathrm{pH}$ exclusively $>7)$.

Fig. 10. Trophic index (epilithon) according to Rott et al. (1999) applied to the CESSPA and CRENODAT springs: (1) ultraoligotrophic, (2) oligotrophic, (3) oligo-mesotrophic, (4) mesotrophic, (5) meso-eutrophic, (6) eutrophic, (7) eu-polytrophic, (8) polytrophic, (9) poly-hypereutrophic. 


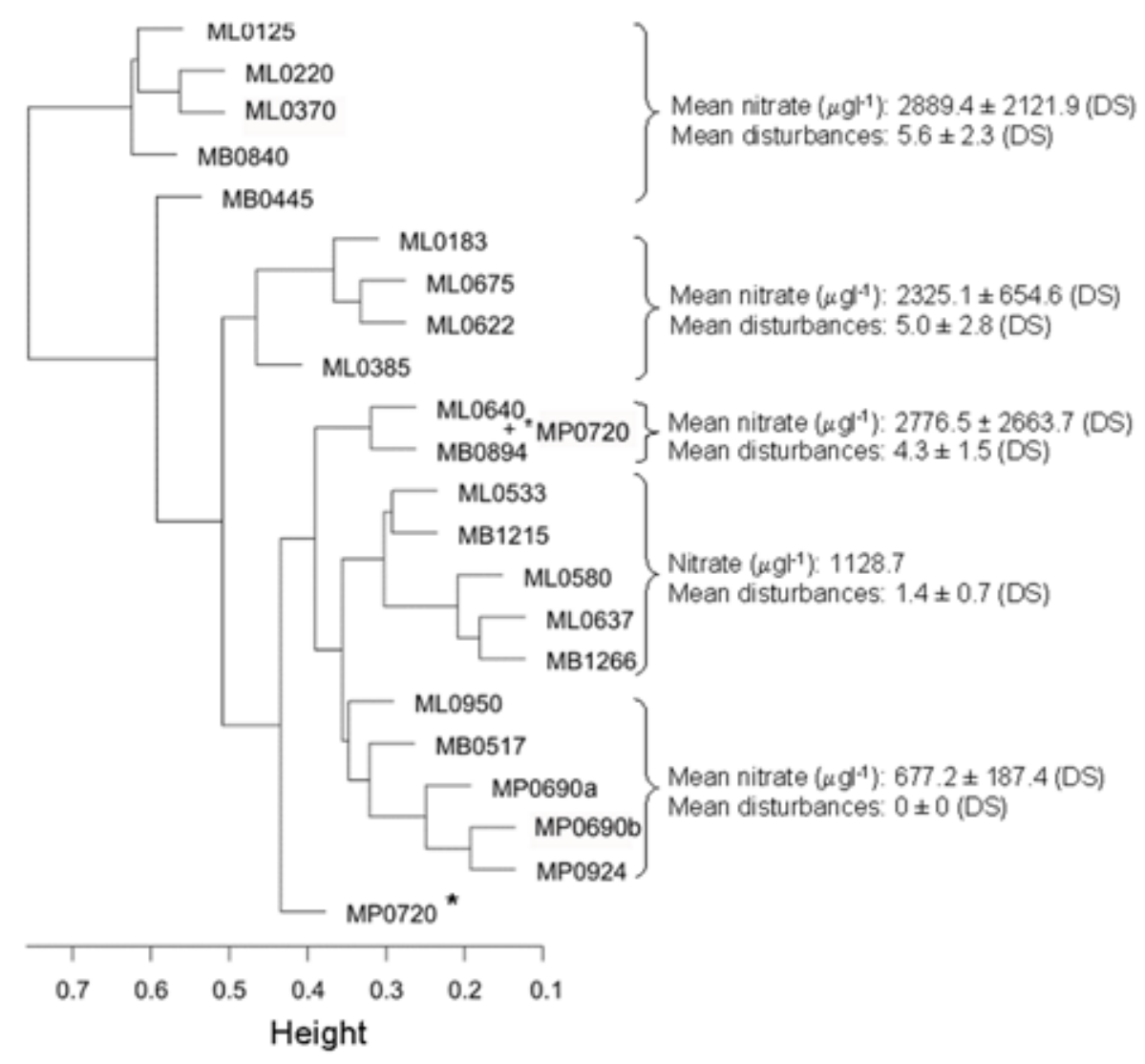

Fig. 11. CESSPA springs' cluster classification according to increasing nitrate values and anthropogenic disturbances (alteration of spring morphology). Labels indicate springs' codes as reported in Table 1.

found (138 CESSPA and 175 CRENODAT when corrected for the number of sites, Fig. 3) appears rather similar when compared to data available in the literature: 131 taxa belonging to 44 genera in 21 springs and streams of the Dolomiti Bellunesi National Park (Cantonati \& Sitale 2009), 118 species in 17 springs in Switzerland (ТАХвӧСК \& Preisig 2007), 115 taxa in 15 springs of the Brenta Dolomites (CANTONATI 1998a,b); 135 taxa in 14 springs BERTRAND et al. (1999), 114 taxa in 15 samples from 5 springs and spring-fed streams on the Island of Mallorca (Delgado et al. 2007). However, it is likely that the slight difference in number of taxa between CESSPA and CRENODAT assemblages might be attributable to causes unrelated to geogenic or geographical factors, because of the similarity of the sites. Rather, it is most probable that the higher species richness of the CRENODAT springs was related to the higher naturalness of those sites (less affected by both anthropogenic alterations of the morphology and nitrate pollution).

The mean total number of taxa found in the individual samples in the present study is always higher for epibryon samples (16 CESSPA vs. 19 CRENODAT respectively) than epilithon samples (14 CESSPA vs. 12 CRENODAT respectively). Epibryon mean total number of taxa were higher for the CRENODAT springs while for epilithon an opposite situation was found (but the difference between the two average values was slightly lower). For the epilithon, the reduction in taxa number due to species selection performed by higher discharge and current velocities in the CRENODAT springs may be more relevant than the effects of morphology alteration and nitrate pollution in the CESSPA springs. ShannonWiener diversity index, although being higher for epibryon samples, is the same in mean value for the two groups of springs (2.4 epibryon - 1.9 epilithon). Werum \& Lange-Bertalot (2004) already noted that the proportion of endangered Red List species was more sensitive to the impact caused by spring-capturing than the value of the Shannon-Wiener diversity index.

Differences are pointed out also by the 
saprobity level, with a greater proportion of oligosaprobic and lower $\beta$-mesosaprobic taxa for the CRENODAT springs as compared to the CESSPA springs. Then, when looking at trophic preferences of epilithic assemblages according to Rотт et al. (1999), ultraoligotraphentic taxa are represented only in the CRENODAT springs while poly-hypereutraphentic ones only in the CESSPA springs. Although the proportions of oligotraphentic and oligo-mesotraphentic taxa are quite similar for both groups, differences appear in a greater percentage of mesotraphentic taxa in the CRENODAT springs with respect to the CESSPA springs, which are dominated by meso-eutraphentic species. Eutraphentic taxa, though being higher in the CRENODAT springs, represent the upper trophic level for these springs while for the CESSPA springs eu-polytraphentic and poly-hypereutraphentic taxa are quite well represented. So it is possible to conclude that CESSPA springs show a higher trophic level (1-2 classes higher) mainly in the medium-upper range of the trophic scale (meso-hypereutrophy).

A recent review by SoININEN (2007) stressed the importance of trophic status and major ions concentration as main environmental determinants in freshwater diatom distribution. Human disturbances and higher nutrient contents seem to be the main factors able to explain differences in species composition and ecology between CRENODAT and CESSPA springs (Fig. 11). Higher nitrate values might mainly be ascribable to diffuse cattle-breeding activities in the area were the CESSPA springs are located.

Higher nitrate values were noted in low altitude, carbonate springs in densely populated areas during previous investigations (ABOAL et al. 1998; Bertrand et al. 1999; Delgado et al. 2007; TAXBÖCK \& PreISIG 2007). ABOAL et al. (1998) pointed out by means of Principal Componenet Analysis the importance of temperature, nitrogen eutrophication, and ionic strength for the grouping of springs. BERTRAND et al. (1999) could note a significant reduction in the number of diatom species with increasing nitrate values.

In spite of this situation showing signs of alteration by anthropogenic impacts, during the present investigation of the CESSPA springs several rare taxa and even a diatom species new to science (Navicula veronensis, unpublished) could be discovered. The new species was found in a highly disturbed site (Torricelle). In this case, the finding of rare and new species is of course not related to the degree of integrity and naturalness of the sites but must be ascribed to the fact that taxonomic analysis was carried out in a very detailed way. This underpins the importance of thorough taxonomic studies of diatom assemblages even in some types of still poorly known types of anthropogenic affected environments (compare WOJTAL 2009).

Although the differences in trophic status and environmental quality between the two groups of springs studied were so marked that even the application of one of the existing diatom-based indices for the assessment of the quality of running waters (RоTT et al. 1999, developed in the Alpine area) could clearly show them, we are aware that the correct approach is to develop an index specific for the geographic area (as suggested also by BeLtrami et al. 2009) and - we believe most important- specific for the category of aquatic habitat (springs). We therefore consider the present paper and previous applications of existing diatom indices to springs performed by our working group (BERTUZzI et al. in prep.) explorative work. The development of a diatom index specific for springs will take advantage from these experiences and is already underway.

\section{Acknowledgements}

We are grateful to the River-Adige Basin Authority and to the Natural History Museum of Verona (in particular Dott. Leonardo Latella) for funding CESSPA Project. Special thanks are due to dott.ssa Nicoletta Verdari and dott. Daniele Fattori (Natural History Museum of Verona) for sampling activity, field data elaboration, and general supervision of the project activities to the Editor-in-Chief Prof. Aloisie Poulíčková and to the Technical Editor Dr. Petr Hašler for valuable improvements of the figures, and to dott.ssa Alessia Scalfi (Museo Tridentino Scienze Naturali) for diatom samples preparation. The CRENODAT Project (Biodiversity assessment and integrity evaluation of springs of Trentino - Italian Alps - and long-term ecological research, 2004-2007), funded by the Scientific Research Service of the Autonomous Province of Trento, offered the possibility to perform the present comparative analysis of spring diatom communities.

\section{References}

Aboal, M., Puig, M. \& Prefasi, M. (1998): Diatom assemblages in springs in Castellón province (Eastern Spain). - Algological Studies 90: 7995. 
APHA (2000): Standard Methods for the Examination of Water and Wastewater. - 20th ed., APHA, AWWA \& WEF, American Public Health Association. Washington D.C.

Beltrami, M.E., Ector, L., Ciutti, F., Cappelletti, C., Hoffmann, L. \& RotT, E. (2009): Longitudinal variations of benthic diatoms and water quality along a large river (Adige River) in Northern Italy. - Verh. Internat. Verein. Limnol. 30: 915918.

Bertrand, J., Renon, J.-P. \& Monnier, O. (1999): Les diatomées des sources du rebord karstique de la Beauce de la région orléanaise. - Symbioses 1: 3-14.

Cantonati, M. (1998a): Diatom communities of springs in the Southern Alps. - Diatom Research 13: 201-220.

Cantonati, M. (ed.) (1998b): 2. La microflora. - In: M. Cantonati (ed.): Le sorgenti del Parco Adamello-Brenta. Parco Adamello Brenta Documenti, 11. - pp. 55-101, Parco AdamelloBrenta, Strembo (Trento).

Cantonati, M. \& Spitale, D. (2009): The role of environmental factors, habitat, and microhabitat in shaping diatom assemblages in springs and streams of the Dolomiti Bellunesi National Park (south-eastern Alps). - Fundamental and Applied Limnology / Archiv für Hydrobiologie 174/2: 117-133.

Cantonati, M., Gerecke, R. \& Bertuzzi, E. (2006): Springs of the Alps, sensitive ecosystems to environmental change: from biodiversity assessments to long-term studies. - In: LAMI, A. \& A. Boggero (eds): Ecology of high altitude aquatic systems in the Alps. Developments of Hydrobiology. - Hydrobiologia 562: 59-96.

Cantonati, M., Bertuzzi, E. \& Spitale, D. (2007): The spring habitat: biota and sampling methods. Monografie del Museo Tridentino di Scienze Naturali 4: 1-350.

Clarke, K.R. \& WARwick, R.M. (1994): Change in marine communities - An approach to statistical analysis and interpretation. - 144 pp., Plymouth Marine Laboratory, UK.

Delgado, C., Ector, L., Novais, M.H., Hoffmann, L. \& PARDO, I. (2007): Diatomées caractéristiques des sources et ruisseaux méditerranéens de l'Île de Mallorca (Îles Baléares, Espagne) 26ème Colloque de l'Association des Diatomistes de Langue FrançaiseAveiro, Portugal, 5-8/09/2007. - In: Almeida, S.F.P., Craveiro, S.C., Rimet, F. \& Ector, L. (eds): Programme scientifique et livre des résumés. - p. 15, Association des Diatomistes de Langue Française \& Université d'Aveiro, Aveiro, Portugal.

EN 13946 (2003): Water quality - Guidance standard for the routine sampling and pretreatment of benthic diatoms from rivers: $1-18$.
Fritscher, J. (2004): Untersuchungen über Sulfi d-Schwefelquellen in Bayern. - 208 pp., Ph.D. Thesis., University of Erlangen, Nürnberg.

Kelly, M.G., Cazaubon, A., Coring, E., Dell'Uomo, A., Ector, L., Goldsmith, B., Guasch, H., Hürlimann, J., Jarlman, A., Kawecka, B., Kwandrans, J., Laugaste, R., Lindstrøm, E.A., Leitao, M., Marvan, P., Padisák J., Pipp, E., Prygiel, J., Rott, E., Sabater, S., Van Dam, H. \& Vizinet, J. (1998): Recommendations for the routine sampling of diatoms for water quality assessments in Europe. - Journal of Applied Phycology 10: 215-224.

Krammer, K. (1997a): Die cymbelloiden Diatomeen. Teil 1. Allgemeines und Encyonema Part. Bibliotheca Diatomologica 36: 1-382.

Krammer, K. (1997b): Die cymbelloiden Diatomeen. Teil 2. Encyonema part., Encyonopsis and Cymbellopsis. - Bibliotheca Diatomologica 37: $1-469$.

Krammer, K. \& Lange-Bertalot, H. (19861991): Süßwasserflora von Mitteleuropa. Bacillariophyceae. Naviculaceae, 2/1. -876 pp.; Bacillariaceae, Epithemiaceae, Surirellaceae, 2/2. - 596 pp.; Centrales, Fragilariaceae, Eunotiaceae, 2/3. - 576 pp.; Achnanthaceae, 2/4. - 437 pp. - In: Ettl, H., Gerloff, J., Heynig, H. \& Mollenhauer, D. (eds). - G. Fischer, Stuttgart. New York.

Krammer, K. (2000-2003): Diatoms of Europe. The Genus Pinnularia, 1. - 703 pp.; Cymbella, 3. 584 pp.; Cymbopleura, Delicata, Navicymbula, Gomphocymbellopsis, Afrocymbella, 4. - 530 pp. - In: LANGE- Bertalot, H. (ed.). - A.R.G. Gantner Verlag K.G, .

Krammer, K. \& LANGe-Bertalot, H. (2004): Bacillariophyceae, Achnanthaceae, 2/4. In: Ettl, H., Gärtner, G., Heynig, H. \& Mollenhauer, D. (eds): Süßwasserflora von Mitteleuropa. - 468 pp., G. Fischer, Stuttgart, New York.

Lange-Bertalot, H. (1993): 85 Neue Taxa und über 100 weitere neu definierte Taxa ergänzend zur Süßwasserflora von Mitteleuropa 2: 1-4. - Bibliotheca Diatomologica 27: 1-454. J. Cramer. Berlin, Stuttgart.

Lange-Bertalot, H. (1996): Rote Liste der limnischen Kieselalgen (Bacillariophyceae) Deutschlands. - Schriften-Reihe für Vegetationskunde 28: 633-677.

Lange-Bertalot, H. (2001): Navicula sensu stricto, 10 Genera separated from Navicula sensu lato, Frustulia. - In Lange-Bertalot, H. (ed.): Diatoms of Europe, 2. - 526 pp.,A.R.G. Gantner Verlag, K.G., Ruggell.

Lange-Bertalot, H. \& Metzeltin, D. (1996): Indicators of Oligotrophy. - In LANGE-BERTALOT, H. (ed.): Iconographia Diatomologica, 2. - 390 pp., 
Koeltz, Koenigstein.

Legendre, P. \& Legendre, L. (1998): Numerical ecology. - 871 pp., Second English edition. Elsevier Science B.V., Amsterdam.

MagurRan, A.E. (2004): Measuring biological diversity. - 260 pp., Oxford, Blackwell Science Ltd.

Poulícková, A., Hásková, P., Krenková, P. \& Hásek, M. (2004): Distribution of diatoms and bryophytes on linear transects through spring fens. - Nova Hedwigia 78: 411-424.

REICHARDT, E. (1997): Taxonomische Revision des Artenkomplexes um Gomphonema pumilum (Bacillariophyceae). - Nova Hedwigia 65: 99129.

Rott,E.,PfisterP.,Pipp,E.,Pall,K.,Binder,N.\&Ortler, K. (1999): Projekt BMLF: Indikationslisten für Aufwuchsalgen in Fließgewässern Österreichs. Teil 2: Trophieindikation und autökologische Anmerkungen. - 248 pp., WWK, Bundesministerium Land- und Forstwirtschaft, Wien.

Round, F.E., Crawford, R.M. \& Mann, D.G. (1990): The diatoms, biology and morphology of the genera. - 747 pp. Cambridge University Press, Cambridge.

Rumrich, U., Lange-Bertalot, H. \& Rumrich, M. (2000): Diatomeen der Anden. - Iconographia Diatomologica, 9: 1-673.

SABATER, S. \& RocA, J.R. (1990): Some factors affecting distribution of diatom assemblages in Pyrenean springs. - Freshwat. Biol. 24: 493-507.

SAbater, S. \& Roca, J. R. (1992): Ecological and biogeographical aspects of diatom distribution in Pyrenean springs. - British Phycological Journal 27: 203-213.

Shannon, C.E. (1948): A mathematical theory of communication. - Bell. Syst. Tech. J. 27: 3742.

Spitale, D. (2007): Assessing the ecomorphology of mountain springs: suggestion from a survey in the South-Eastern Alps. - In: CANTONATI, M., Bertuzzi, E. \& Spitale, D. (eds): The spring habitat: Biota and sampling methods. Monografie del Museo Tridentino di Scienze Naturali 4. - pp. 31-44, Museo Tridentino di Scienze Naturali, Trento.

SoININEN, J. (2007): Environmental and spatial control of freshwater diatoms - a review. - Diatom Research 22: 473-490.

TAXвÖck, L. \& Preisig, H.R. (2007): The diatom communities in Swiss springs: A first approach.In KusBer, W.-H. \& JAHN, R. (eds): Proceedings of the 1st Central European Diatom Meeting. - pp. 163-168, Botanic Garden and Botanical Museum Berlin-Dahlem, Freie Universität Berlin.

Tolotti, M. (2001): Littoral diatom communities in high mountain lakes of the Adamello-Brenta Regional Park (Trentino, Italy) and their relation to acidification. - In JAHN, R., KociOLEK, J.P., Witkowski, A. \& Compère, P. (eds): LangeBertalot-Festschrift. - pp. 327-352, Gantner, Ruggell.

Torrisi, M. \& Dell'Uomo, A. (2009): Diatomee bentoniche del corso superiore di alcuni fiumi centro-appenninici. - Studi Trent. Sci. Nat., Acta Biol. 84: 15-20.

van Dam, H., Mertens, A. \& Sinkeldam, J. (1994): A coded checklist and ecological indicator values of freshwater diatoms from the Netherlands. - Netherlands Journal of Aquatic Ecology 28: 117-133.

Werum, M. \& Lange-Bertalot, H. (2004): Diatoms in Springs from Central Europe and elsewhere under the influence of hydrogeology and anthropogenic impacts. - In LANGE-BERTALOT, H. (ed.): Iconographia Diatomologica, 13. - pp. 1-417, Koeltz, Koenigstein.

Wojtal, A. (2006): The influence of environmental variables on diatom distribution in springs of the Krakowsko-Czestochowska upland (S. Poland) $-19^{\text {th }}$ International Diatom Symposium (28 August - 3 September 2006, Listvyanka, Lake Baikal, Russia). Abstract Book: 168.

Wojtal, A. (2009): Diatom flora of Kobylanka stream. How many taxa can exist in a very small waterbody? - Studi Trent. Sci. Nat., Acta Biol. 84: 135-138.

Wojtal, A.Z. \& SolaK, C.N. (2009): Diatom assemblages in calcareous springs in Poland and Turkey. - In De Wolf, H. (ed.): $3^{\text {rd }}$ Central European Diatom Meeting, CEDIATOM3, Abstract Book, Diatomededelingen, 33. - p. 130, Utrecht, The Netherlands.

\footnotetext{
(C) Czech Phycological Society

Received May 9, 2009

Accepted August 11, 2009
} 